\title{
Alcman at the end of Aristophanes' Lysistrata: ritual interchorality
}

\author{
Anton Bierl
}

\section{Preliminary remarks: recent research on the chorus}

The notion of the 'choric' and research on the Greek chorus have lately been in vogue. ${ }^{1}$ In the last few decades it has proved particularly fruitful to trace a direct line of continuity from archaic choral poetry to the chorus in drama. ${ }^{2}$ Many critics, including myself, have recently highlighted the ritual aspect of choreia. The 'performative turn' has brought into focus precisely the performative and ritual aspects that will be of great significance for the following interpretation. ${ }^{3}$ Let me summarise a few of these findings.

1 A slightly modified version of this article appeared in Italian as ' $L$ 'uso intertestuale di Alcmane nel finale della Lisistrata di Aristofane. Coro e rito nel contesto performativo', in F. Perusino/M. Colantonio, ed., Dalla lirica corale alla poesia drammatica. Forme e funzioni del canto corale nella tragedia e nella commedia greca, Pisa 2007, 259-90. I would like to thank Elaine Griffiths for the translation of the German typescript and Ewen Bowie for further adjustments. Furthermore I cordially thank Lucia Athanassaki for the kind invitation to Rethymnon and all participants for the excellent discussion of my paper. My thanks go also to Chris Carey, who shared with me his interesting results on Alcman's textual transmission. Last but not least I wish to thank Lucia Athanassaki and Ewen Bowie for their excellent job as editors. For the recent work on the chorus see Calame 1977 I (Engl. 1997); Nagy 1990, esp. 339-81; Lonsdale 1993; Golder/Scully 1994/95 and 1996, 1-114; Henrichs 1996; Stehle 1997; Ceccarelli 1998; Wilson 2000; Bierl 2001 (Engl. 2009); Foley 2003; Murray/Wilson 2004.

2 On continuities between melic choral lyrics and dramatic choral songs see, among others, Herington 1985, 103-24; Nagy 1990, 382-413 and 1994/95; Bierl 2001 (Engl. 2009); Swift 2010. On the tragic chorus see recently Calame 1994/95; Henrichs 1996; Käppel 1999, esp. 61-69. On the comic chorus see Bierl 2001 (Engl. 2009).

3 Bierl 2001, 22-37 (Engl. 2009, 11-24). In the latest monograph on Aristophanes, likewise dedicated to the 'performative turn', Revermann 2006 does 
Choral dance is ritual par excellence. Choral dance movements are only one dimension of a performative, multi-media presentation. Song and non-verbal sign language are part of a metaphoric communication of paradigmatic actions. In a marked, ritual way patterns of behaviour are practised through the body, then performed to an audience in an agonistic context. ${ }^{4}$ The insistent rhythm, the collective stamping and acting out of the group's ideological and religious foundations - simultaneously communicated through song - all enhance its sense of cohesion.

In all, the chorus often constitutes a microcosm of a polis and is closely connected to its symbolic culture. The gods, in whose honour choruses are performed, are strongly anchored in the ideological order of the community. Thus, choruses are always set in a cultic, ritual context: they perform on the occasion of festivals and religious ceremonies. Precisely in the three paradigms put forward by modern religious studies (initiation, harvest, and fertility associated with the beginning of a New Year) choruses play a major role, and one and the same occasion is often related to all three paradigms.

For the dramatic chorus, which no doubt emerged from the culture of actual choral song, a very important factor is its dual rootedness in fiction as well as in the here-and-now of the performance, and its oscillation between these levels. 'Choral self-references' and 'projections" strengthen the act of choreia. ${ }^{6}$ Purely ritual choruses for routine performance are distinguished by the fact that they point to their own action; the choral group acts out the action in movements that correspond to the performative statements that are their words.

The comic chorus resembles simple ritual choruses in many respects. In contrast to their tragic equivalent there is here a dearth of long narrative passages. Instead, the words of many comic choruses devote themselves entirely to the current ritual action, to prayer, to the hymnos kletikos, and to merry, celebratory dance. ${ }^{7}$

Greek choruses were originally closely linked to paideia, i.e. to education in the broadest sense. ${ }^{8}$ In the archaic period boys and girls were

not take into consideration my own approach to the issue as set out in Bierl 2001 (Engl. 2009).

4 Bierl 2001, 31 (Engl. 2009, 19); Lonsdale 1993, esp. 19; see also Tambiah 1985, 123-66, 382-89, esp. 124, 149-50, 154-55, 164.

5 Henrichs 1994/95, 68, 73, 75-90.

6 Bierl 1991 and 2001 (Engl. 2009); Henrichs 1994/95; Calame 1999a.

7 Bierl 2001, esp. 64-96 (Engl. 2009, esp. 47-75).

8 In their staged, emotional theatricality choral performances are most comparable to ritual play. As an essential part of education, choreia is, on one hand, a means of social control and thus fosters the handing on of values and norms of 
prepared for the transition to adult life in such a choral group. The traditional character of such initiation practices has been clearly brought out in the last few decades, starting with Claude Calame's epochmaking thesis in 1977. ${ }^{9}$ The Spartan girls' choruses as presented in Alcman became understandable from this angle, as does Sappho's circle. ${ }^{10}$ Even in the transformation of the chorus into drama, these original features remained partially preserved and also influenced the development of the plot. ${ }^{11}$

\section{Alcman's reception in Athens and inter-chorality}

In addition to the cultural function of the Greek chorus it will be particularly relevant for the following reflections on the relationship between Aristophanes and the partheneia of the archaic Spartan choral poet Alcman to consider the methodological perspectives of intertextuality. ${ }^{12}$ This area of research examines the question of how literary texts tend to relate to the canonical authors and give rise to new webs of meaning. In the specific case of the end of Lysistrata we might prefer to speak of inter-performativity, inter-rituality or even inter-chorality. Through the re-enactment of a chorus by the actual dramatic chorus an interactive play of choral performances is being established, which creates deeper meaning on an emotional and ritual level.

Alcman is not actually cited in the final lines of Lysistrata. However, through the dramatist's evocation of a specifically Spartan cultic mood, the mention of dancing parthenoi by the banks of the Eurotas and, not least, through the insertion of features characteristic of high lyric in the dialect and rhythm of Spartan poetry, spectators with a certain amount

a society. On the other hand, choral performances partially resemble ritual drama that can temporarily turn the world upside down.

9 Calame 1977 I (Engl. 1997). Generally on the paradigm of initiation see Calame 1999c, Bierl 2001, Index under 'Initiation', esp. 35-36 with n. 61 (Engl. 2009, Index under 'rite de passage', esp. 22-23 with n. 61), and Burkert 2004, esp. 118-23. On the educational aspect of initiation dances see e.g. Bierl

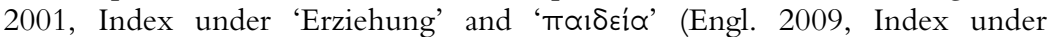
' $\pi \propto{ }_{1} \delta \varepsilon \mathbf{i}^{\prime}$ '); Ingalls 2000. See the critical assessment of the paradigm in Dodd/Faraone 2003.

10 Bierl 2003.

11 Winkler 1990a; Nagy 1994/95a; Bierl 2001 (Engl. 2009) .

12 See e.g. Genette 1982; Schmid/Stempel 1983; Broich/Pfister 1985; Holthuis 1993; Schahadat 1995; Fowler 1997 (with a good bibliography 32-34); Hinds 1998, esp. 17-51. 
of literary knowledge would be immediately reminded of the maiden songs (partheneia) of the famous ancient poet Alcman, known to us primarily through two major finds (frr. 1 and $3 P M G F=$ frr. 3 and 1 Calame).$^{13}$ In short, in this case it is more of an allusion than a clear individual textual reference, ${ }^{14}$ i.e. it is a case of choral intertextuality largely based on implicitness, ${ }^{15}$ where an atmospheric topos points us to Alcman. ${ }^{16}$

At this point we touch on the thorny issue of whether and how Alcman could be known to the wider Athenian public. I agree with Chris Carey who in this volume argues for a preservation of Alcman's text in Sparta, where it was used in an annually re-performed festival. Despite all his locally-centred interest in Spartan cult and festivals, Alcman's poetry also revealed aspects that transcend Laconian practice. Like any poet, he was eager to become famous in the elitist circles of the pan-Hellenic aristocracy; and Sparta, as a fairly open society, had an interest in exhibiting her culture in order to gain prestige all over Greece. Some texts of Alcman's masterpieces already circulated more widely in the classical period. These, of course, also reached Athens, the cultural centre, which played a pivotal role in their further dissemination. Thus, some highly educated men in the audience might have even been able to recognise direct textual references. It is also probable that a fair number of the people in the theatre had already heard a maiden song of Alcman; perhaps in an aristocratic gathering they had witnessed a performance of Alcman, the pinnacle of Spartan and common Greek culture. In their mind it was still clear that these words were actually sung and performed in a Spartan choral setting. Having themselves grown up in a choral culture, they will somehow have become familiar with Spartan choruses of parthenoi. And the majority of the spectators might have at least a faint idea of such performances and their ritual meaning. In cultural matters they must have felt admiration and at the same time disdain for the enemy. Aristophanes designed his play in such a way as to address various strata of society. But by not indicating the name of Alcman in the pastiche at the end of Lysistrata, and by recreat-

13 P. Louvre E 3320. I quote Alcman after PMGF. Fundamental: Page 1951; Calame 1977 II and 1983, 28-49 (text of fr. 3 Calame) and 311-49 (commentary); West 1965; Puelma 1977; Segal 1983; Clay 1991; Pavese 1992; Robbins 1994; Clark 1996; Peponi 2004; Hinge 2009.

14 Pfister 1985, esp. 26-30; Broich 1985a and 1985b.

15 On the implicitly marked intertextuality see Helbig 1996, 91-97. On implicitness as a sign of intertextuality see also Grivel 1983, esp. 55-57.

16 Hinds 1998, 100-104; on allusion via a topos see Plett 1985, esp. 78-80, 96-98. 
ing an atmosphere in very general terms, he appealed chiefly to the projections of the majority.

The reference to Alcman's maiden songs, their choral reperformance on stage, is, in my view, of particular relevance for the plot of Lysistrata. Through their sex-strike the women here symbolically revert to the state of virgins, who are forbidden to have sexual intercourse before marriage. ${ }^{17}$ Consequently the happy ending notionally enacts the remarriage of the couples. Since Alcman's songs are about girls on the verge of marriage, i.e. adulthood and ritual transition, Aristophanes stages the end of the interrupted marital order as a choral celebration that makes specific reference to them. ${ }^{18}$ In this way he succeeds in making the Athenian audience understand the imminent renewal of the marriages in emotionally and culturally familiar terms. This is particularly easy to do, since the comic dispute is about a conflict with Sparta, Alcman's place of work.

\section{The plot of Lysistrata and the role of the chorus}

It is well-known that Lysistrata, like some other comedies of Aristophanes, addresses in simple plot-terms the theme of peace in Hellas, plagued as it is by the Peloponnesian War. ${ }^{19}$ The heroine has the amusing idea of undertaking two courses of action in order to induce the men to abandon their warring activities: A) She gets the women to stage a pan-Hellenic sex strike; B) She and other older women occupy the Acropolis in Athens, in order to gain control of the state funds stored there and, thereby, the power to wage war. This comedy is original in at least one respect: the protagonist and heroine is a woman. Of course,

17 See Loraux 1993, esp. 162-66; on a similar backward time-shift in Ar. Th. see Bierl 2001, 225-87 (Engl. 2009, 196-254).

18 The ritual grounding remains disputed; the following scholars argue for an initiation: Calame 1977 II (only of Agido as the outstanding girl in the group) and Clark 1996; the following read the partheneion (fr. 1) as an epithalamion or wedding song: Griffiths 1972; Gentili 1976 and 1991 (who argues for a homosexual initiation-marriage between Hagesichora and Agido in a female thiasos). These two theories are not necessarily contradictory, since wedding is the goal of the initiation.

19 Recent commentaries: Henderson 1987; Sommerstein 1990; recent secondary literature: Lewis 1955; Hulton 1972; Vaio 1973; Rosellini 1979; Henderson 1980; Foley 1982; Martin 1987; Loraux 1993, 147-83; Faraone 1997; Dorati 1998 and 1999; Fletcher 1999; Grebe 1999; Perusino 1999 and 2002; Hawkins 2001; Culpepper Stroup 2004; Andrisano 2007. 
one should not jump to the conclusion - as many have - that Lysistrata is a proto-feminist play. Women had no power at all in Athenian public life, except in cult. ${ }^{20}$ In Old Comedy, allowing women to take over was a typical motif showing a world turned upside down. Precedents are found only in the realm of myth, e.g. the Amazons.

This is why myth and ritual are so important to understanding this comedy. ${ }^{21}$ As I will attempt to make clear elsewhere, Lysistrata is based on the heortological sequence in the Athenian festival calendar from the Scira to the Panathenaea and thereby primarily on the rites connected to the initiation of young men and women. At the same time, however, it is also about the crisis-ridden transition from the Old Year to the New and about the harvest. If women take action on the Acropolis, and - to add insult to injury - deny their sexuality, they are associated by the audience either with mythical models of a counter-world gynaecocracy or with the arrhephoroi, young girls who devote themselves over eight months in cultic service to Athena Polias on the Acropolis. Above all, they weave a robe that is ceremonially presented to Athena at the Panathenaea, a festival at which the young people present themselves for marriage. ${ }^{22}$ Lysistrata acts outside the sex-focused action of the other women and directs the whole almost like a deity with grace (charis), intelligence, rhetoric and persuasion (peitho). In many ways she is comparable to the goddess Athena, the mistress of the city and the Acropolis, who is magically able to compel her opponents to surrender. In some respect, she seems to be a comic equivalent to the Athena of Aeschylus' Eumenides. The perceptible proximity to the eponymous polis goddess is underlined by the fact that the name of the heroine may be associated with that of Lysimache, a famous priestess of Athena Polias in this period. ${ }^{23}$ Aristophanes thus toys etymologically and metonymically with the significance of the two names, which signify the 'dissolution of an army/a battle'.

In accordance with Old Comedy's preference for physical elements and corporality, ${ }^{24}$ the Acropolis turns into a fantastic uterus by means of polytropic language movements through metaphor and metonymy, similes and contiguity. ${ }^{25}$ In this way, contrary to the laws of probability,

20 On the role of women in society and gender issues see (from the mass of secondary literature) e.g. Peradotto/Sullivan 1984; Blok/Mason 1987; Winkler 1990b; Späth/Wagner-Hasel 2000.

21 Bowie 1993, 178-204; Martin 1987.

22 On the ritual background see Burkert 1966 and Baudy 1992.

23 Lewis 1955; Connelly 2007, 11-12, 62-64.

24 On the body see Bierl 2011 [forthcoming].

25 Whitman 1964, 203 with n. 9. 
the sex-strike is linked to the occupation and barricade of the holy citadel of Athens. Through the performance, dance movements and the sung words of the chorus, plots are created in metaphorical speech-acts ${ }^{26}$ that correspond to these metaphorical shifts: the Acropolis becomes the female sexual organ, and the sex-strike (Plan A) merges with the occupation (Plan B). In addition, the old women become girls, the old men increasingly become ephebes. ${ }^{27}$ The chorus determines the plot and accompanies it at another level. Lysistrata's initiative leads to the dramatic division of the sexes, whose contact, moreover, has already been considerably disturbed by the Peloponnesian War (99-106). However, the action is planned in such a way that the interruption of sexual relations between husband and wife does not lead to a final separation. Instead, the men are to feel special desire for their partners through their erotic appearance and thereby succumb to their sex appeal $(42-53,149-$ 54, 217-22). Through constant sexual frustration - this is the plan - the exclusi amatores will finally agree to conclude a peace deal with one an-

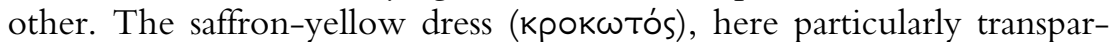
ent ${ }^{28}$ precisely recalls the Brauronia, another rite de passage of young girls before marriage, which is ritually performed at the Panathenaea. ${ }^{29}$ This development of cultic roles from arrhephoroi, to girls of Brauron and to

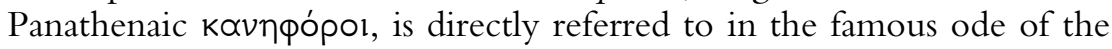
women in the parabasis $(638-48) .^{30}$

The separation of the sexes is underlined in the performance by the division into a male and a female half-chorus. Through the sex ban and the blocking of the cultic centre of the polis, the two groups find themselves clashing violently during the whole play, a clash which is played out as speech acts in words and dance. ${ }^{31}$ In the parodos (258-386) the half-chorus of old men first comes up the steps of the Propylaea with powerful logs, to be used as battering rams, and fire-pots. The women defend the steps and tip water all over them. The men remind one of phallophoroi, carriers of giant phalloi, and, in the case of the younger husbands, the logs finally turn into 'real', erect male organs. The fire sym-

26 Newiger 1957.

27 On the connection between plans A and B see Vaio 1973, 369-71, 376-78.

28 Line 44, 47, 219-20; see line 48, 150-51. See Hamilton 1989, 461 with n. 28. For an interesting connection between the Arkteia, the krateriskoi at Brauron,

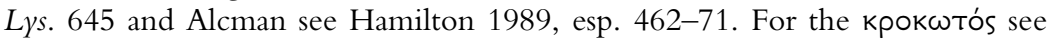
now Andrisano 2007, 10-15.

29 Gentili/Perusino 2002 and Perusino 2002.

30 Sourvinou-Inwood 1971 and 1988; against her textual conjecture see Grebe 1999 and Perusino 2002.

31 On violence see Perusino 1999. 
bolises the sex-drive, the water abruptly cools this desire and is ironically

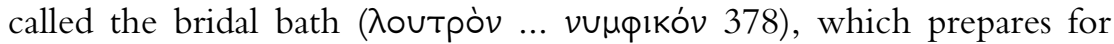
the final wedding. ${ }^{32}$ As the plot moves on the old people, especially the

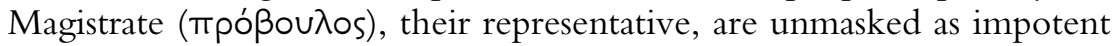
in their phallic pose.

The violent battles between the half-choruses drag on far beyond the first half of the comedy. It is a long tussle reaching from the parodos through the actual choral debate, the agon (476-613), to the parabasis, here a double parabatic syzygy (614-705), that again takes on the character of an agon. The choral interludes, in the form of competitive and recriminatory songs of exchange (amoibaia) after the comic attempts to escape, use mythical examples to underline the men's hatred of the female sex (Melanion), ${ }^{33}$ the women's desire and the simultaneous contempt for the men of one man (Timon) (781-828). However, the halfchoruses are now less involved in the plot; they stand by and comment on what happens. After the plan has been impressively illustrated by Cinesias in a scene of play-acting with Myrrhine (889-953, 954-79), a Spartan counterpart appears on the stage (980-1013), a herald suffering from priapism or ithyphallic spasmos $(845,1089)$. Since this disease has become so terrible on both sides of the war that there were signs of surrender, the men send an envoy with full powers to both cities, Sparta and Athens, in order finally to make peace and, thereby, to be able finally to sleep with their wives again. At this point, a premature reconciliation emerges at the level of the chorus (1014-1042). The old men, who in their rage have uncovered their torsos like the women (615, 663-64, 687-88), are now wrapped up (1019-1042) and the women help to remove a giant gnat, a symbol of the anger, from the eyes of the old men. ${ }^{34}$ There are kisses all around and finally reconciliation is established between the half-choruses that have hitherto directed their fury at each other.

They now turn to the audience in two songs. The first tells, in two strophes (1043-1071), the tale of how the money stored on the Acropolis can soon be distributed; they evoke a banquet from which finally all people will be excluded; peace is anticipated and then amusingly negotiated on the stage (1112-1188, esp. 1159-1188). Lysistrata produces the nude female personification of Reconciliation $(\Delta \iota \propto \lambda \lambda \propto \gamma \eta \dot{\eta})$ and mediates by reminding the Athenian and Spartan legates of their common rituals and history. Quarrels about territory are comically projected upon the

32 Dorati 1999.

33 On the motif of the Black Hunter see Vidal-Naquet 1986.

34 This scene hints at sexual satisfaction. 
image of the attractive female body and settled according to ethnic preferences in sexual practices. Finally, the peace agreement is sealed with a festive drinking party celebrated at the back of the stage. In another interlude (1189-1215), the chorus now offers richly to equip each boy and, above all, each girl that carries the basket at the Panathenaea as kavnфópos (1194); the audience too - here the chorus now turns increasingly to the external level of the here-and-now - is invited to participate in the abundance of grain via a choinix, the measure of a man's daily allowance, that also suggests Athena in her function as goddess of marriage..$^{35}$ Only please don't take anything from his house, the chorus jokes in typical fashion (1213-1215; cf. 1071). The Panathenaea and the rites of marriage associated with Athena then serve conceptually to situate the exit song (exodos), in which the success of the joint drinking party is now celebrated with elation on stage. Bands of revellers ( $\kappa \tilde{\omega} \mu \mathrm{o})$ are characteristic of exodoi and symposia. A crowd, probably the chorus, has gathered outside around the gate in order to enjoy some of the party inside. Then the Athenian delegate threatens to use force, if the chorus does not move on (1216-1222). Finally the Spartans and Athenians march out as masters of the feast (1241).

\section{The exodos}

The Spartan delegate orders the pipe-player to play the tune 'so that he can dance and sing a two-step to the Athenians and himself (12421244). The Athenian delegate underscores this demand, saying that he

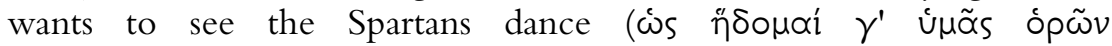

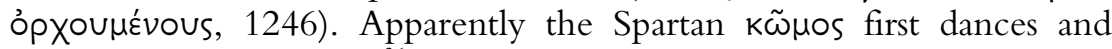
sings the following song: ${ }^{36}$

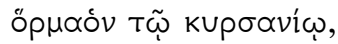

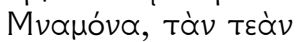

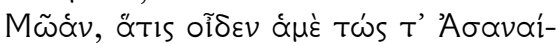

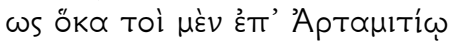

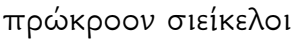

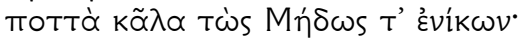

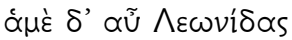

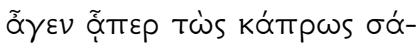

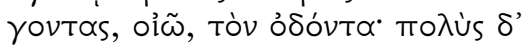

35 Deubner 1932, 15-16. See esp. Arist. Oec. 1347a14.

36 For this and the following quotations from Aristophanes I give the text of Henderson 1987 and (slightly modified) translation of Henderson 2000. 


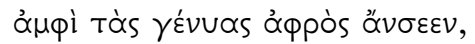

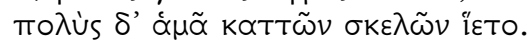

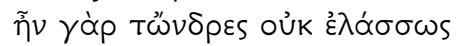

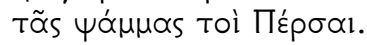

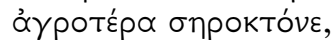

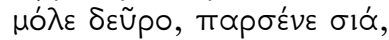

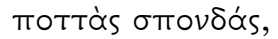

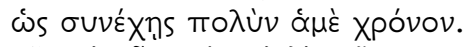

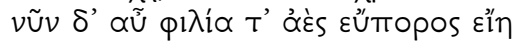

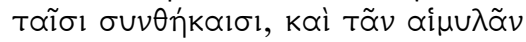

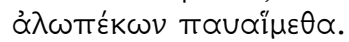

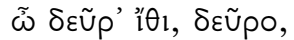

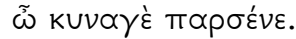

(Ar. Lys. 1247-1272)

Memory, speed to this lad your own Muse, who knows about us and the Athenians, about that day at Artemisium when they spread sail like gods against the armada and defeated the Medes; but we for our part were led by Leonidas, like wild boars we were, yes, gnashing our tusks, our jaws running streams of foam, and our legs too. Their warriors outnumbered the sands on the shore, those Persians. Goddess of the Wilds, Beast Killer, come this way, maiden goddess, to join in the treaty, and keep us together for a long time. Now let friendship in abundance attend our agreement always, and let us ever abandon foxy stratagems. O come this way, this way, o Virgin Huntress!

Mnemosyne, 'Memory' and mother of the Muses, is asked to bring (ópũ̃ $\nu, 1247)$ dance and song to the men, i.e. to be their Muse. That is because, by means of memoria, the common successes of the past against the Persians can be hymned in earthy Spartan tones, the Athenian victory at Artemisium and the heroic Spartan deeds of Leonidas and his 300 at Thermopylae. ${ }^{37}$ Finally, Artemis Agrotera, as the Athenians called the killer of wild animals responsible for massacring the enemies they call wild boars (1255), is now invited to appear as the guarantor of the peace

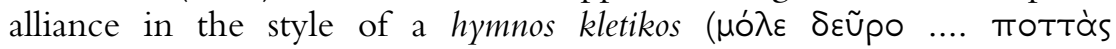

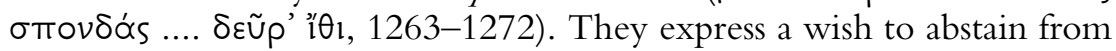
clever tricks in future. The Spartan dance, the overall diction and the dialect are associated with the wild and uncivilised outside world. By its act of remembering, the performance creates cohesion among the Spartans themselves, but also common ground with their adversary in war, Athens - their former ally in the pan-Hellenic war against the Persians. Artemis is for them the slaughterer of the barbarians of the past, but now as the goddess of the wilderness she is also the ideal partner and

37 The substantial model as regards the content of this song is not Alcman but Simonides. 
leader of their $\kappa \tilde{\omega}$ Mos, whose members define themselves only by means of animal terms. At the same time, she is also a cultic focus for the highly aroused men of both cities, who thereby, after their peace agreement, can offload their aggression onto a shared external enemy.

Most scholars assume that this passage was a monody, and the Spartans are held only to have danced to it. This interpretation is probable, but it is also possible that all the Spartan ephebes appeared in a

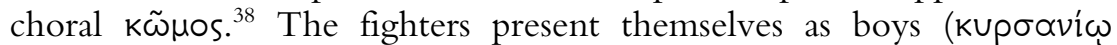
1247; cf. earlier in 983) in order to unite with the 'rejuvenated' women in the chorus. The ephebisation has, among other things, to do with the

38 In this case there would also be a secondary chorus of Spartans as proposed by some early editors like Meineke or Blaydes; see also Muff 1872, 117-19. The latter also postulates an Athenian secondary chorus; according to him a union with the chorus takes place at the end in the orchestra with everyone marching off together; Muff presents the following distribution (161-62): 1247-1272 'ein

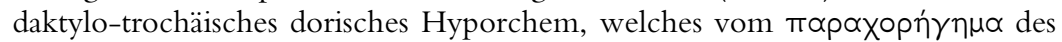
Lakoner-Chors zum Spiel der Flöte und zum Tanze gesungen wird' ('a dactylo-trochaic Doric hyporcheme, sung by the $\pi \propto \rho \alpha \chi \circ \rho \eta \eta \gamma \eta \mu \alpha$ of the Laconian chorus accompanying the sound of the pipe appropriate for dancing'); 12731278 Lysistrata; 1279-1294 'ein daktylo-trochäisches Hyporchem, vom

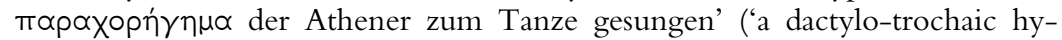

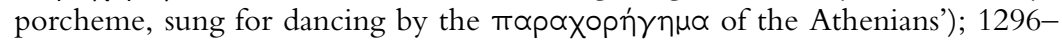
1322 'ein daktylo-trochäisches Hyporchem, vom Parachoregem der Lakoner zum Tanze gesungen' ('a dactylo-trochaic hyporcheme, sung for dancing by the parachoregeme of the Spartans'). Beer 1844, 9 thinks, in contrast, that the Athenian chorus was not a special secondary chorus, 'but the usual, still present chorus of Athenian women and old men must have sung it.' Arnoldt 1873, 169-71 takes the line that Beer 1844 has not been refuted, i.e. 1279-1295 was performed by the usual chorus; $1247-1272$ and 1296-1322 are only sung by the choral leader, not by the whole chorus, which only dances to it; also 12791292 is sung by the leader of the usual chorus; the refrain consists only of 1293-1294 and was sung by the whole chorus (170-71); Muff 1872 thinks hard about the division between choral leader, whole chorus and half-chorus, and sets out useful categories. In sum, I return in my analysis to the older criticism, particularly to Muff's solution, which is also supported by the manuscripts.

Recently, the usual distribution of the lines (esp. Zimmermann 1985, 42-49 and 80-81 and Henderson 1987) is as follows: 1247-1272 Spartan delegation leader; 1273-1278 Athenian delegation leader; 1279-1290 Athenian delegation leader (Sommerstein 1990 and Wilson 2007 attribute 1273-1290 to Lysistrata); 1291-1294 semi-chorus (against: 1279-1294 chorus B, also Blaydes 1880-93, Hall/Geldart 1906-1907², Wilamowitz-Moellendorff 1927, Coulon 19231930; see also Perusino 1968, 57-60 and Kaimio 1970, 127); 1295 Athenian delegation leader (Sommerstein and Wilson attribute the verse to Lysistrata); 1296-1321 Spartan delegation leader. For an overview of the disputed character distribution see Thiercy 1995. 
fact that, as I have outlined elsewhere, Greek comasts projected themselves notionally back to the marginal phase of their ephebic initiation, just as the women do in this play. ${ }^{39}$ The liminality of the 'black hunter' is expressed in their completely uncivilised, almost animal-like behaviour. ${ }^{40}$ The Spartans have the situation more under control, despite their naivety. The Athenians are irresistibly drawn into the alliance by the emotionality of such a song, stressing the points they have in common. It still requires a bit of direction by Lysistrata. ${ }^{41}$ After peace has been made between the men, she finally wants to bring about the union of the sexes, i.e. the bonding of the married couples.

Lysistrata therefore calls upon the Spartans and the Athenians to lead their wives away (1274-1275). Lysistrata had already mentioned that, after the celebration, each of them was to take his wife and go home (1186-1187). It is not quite clear how the Spartan women have now come onto the stage. Were they among the hostages (244) who are finally brought forth by Lysistrata, or were Lampito and her companions allowed to come with the Spartans? ${ }^{42}$ One may certainly imagine that the female part of the secondary chorus of the united Athenians was also played by women from the main chorus.

For the outgoing march, Lysistrata sets up a line of couples and calls on the Spartans and Athenians to dance for the gods to mark the happy

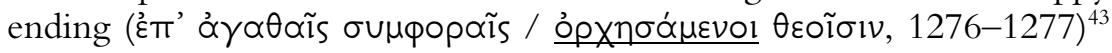
and to be careful not to do evil again (1273-1278). In a chiastic form the united Athenian secondary chorus starts off by praising the gods:

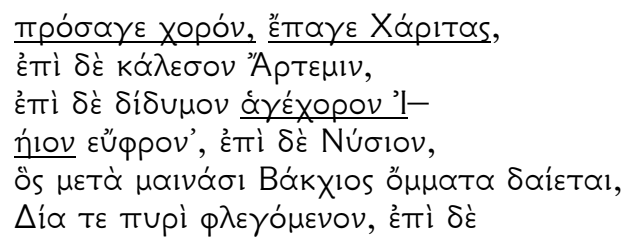

39 Bierl 2001, 313, 318 n. 48, 341 n. 105, 358 n. 140 (Engl. 2009, 279, 284 n. 48, 306 n. 105, 322 n. 140).

40 Bierl 2001, 322, 366-67 (Engl. 2009, 287, 331-32).

41 Wilamowitz-Moellendorff 1927 and Henderson 1987 assume that the Athenian delegate speaks here.

42 Lampito is already associated with feminine beauty $(79-80,83)$, sport and

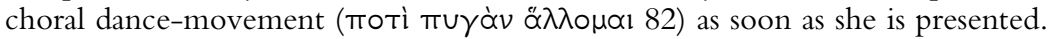
On $\pi \eta \delta \delta \dot{\alpha} \omega$ and $\alpha{ }^{\prime} \lambda \lambda_{0 \mu \alpha 1}$ as choral terms see Naerebout 1997, 281-82. Calame 1977 I, 408 (Engl. 1997, 236-37) wants to relate the passage to the running at the Platanistas, in the context of which he also seeks to place L $y s .1308-1315$.

43 Here and in the following passages I have underlined words and phrases that are explicitly self-referential in the manner of lyric choruses. 


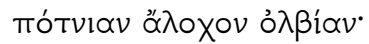

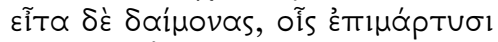

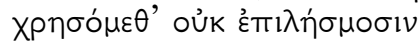

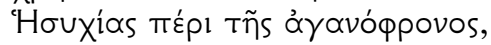

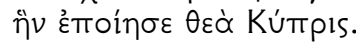

(Ar. Lys. 1279-1290)

Bring on the dance, bring in the Graces, and invite Artemis, and her twin brother, the benign Healer, and the Nysian whose eyes flash bacchic among his maenads, and Zeus alight with flame and the thriving Lady his consort; and invite the divine powers we shall have as witnesses to remember always this gentle-minded Peace, which the goddess Cypris has fashioned.

Almost all modern editors and interpreters assume, as with the following Laconian secondary chorus, that there follows a solo song by the Athenian or Spartan delegate. The Spartan monody (1247-1272) is followed by one by the Athenian in astrophic form, then again one by a Spartan; after peace has been made the chorus no longer plays an active role. The reconciliation ensues at the level of the actors; in the context of a symposium the song is always monodic. ${ }^{44}$ Here, as in the next song of the Spartans, scholars were mainly misled by the demand in the second person singular, which was interpreted as an indication of a soloist. Yet in ritual choruses, particularly in comic ones, instructions are frequently given to the whole chorus in the singular, ${ }^{45}$ just as the chorus switches between the singular and plural of the first person.

The repeated choral self-references clearly indicate a choral perform-

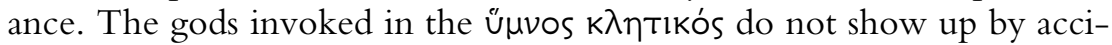
dent, rather they form a programmatic group both in the intra- and the extra-fictional context. The Graces (Xópıtes) closely bound up with Aphrodite constitute the personification of female charm and sexual attraction presupposed for fertility. They naturally also belong to the performance of a song. ${ }^{46}$ There follows Artemis, already mentioned by the Spartans. Now, she no longer serves as the goddess of the outside, but is addressed with her brother Apollo, since both function as the deities of choral dance and above all of the initiation of girls and young

44 Zimmermann 1985, 45-46. He speaks of monodies (81) accompanied by dance; according to Sommerstein 1990 Lysistrata continues to speak until 1290. Cingano 1993 considers it probable that Stesichorus, Pindar and Alcman were performed by a chorus and not by a solo singer.

45 Th. 953, 961, 969, 981, 985; Ra. 340, 372, 378; see also Ach. 299, 361, 675; Eq. 329; Nu. 461; Av. 334. See also Muff 1872, 29-32; Norden 1939, 193-99; Kaimio 1970, 127-28; Bierl 2001, 121 with n. 29 (Engl. 2009, 98 with n. 29).

46 Pax 796-97; Av. 782, 1320; Ar. fr. 348 K.-A. On the radiance as an expression of xápıs of the nubile girl in Sappho see Brown 1989. 
men. ${ }^{47}$ Naturally there is also a plea for the epiphany of Dionysus, the god of the performance, who is also in a state of sexual exchange with his maenads. Then, the divine couple Zeus and Hera are called down to symbolise the re-celebration of the marriage between the couples at the Olympian level. Further gods are called as witnesses in order to ensure that the bond of peace and calm forged by Aphrodite will never be forgotten. After the Spartans have evoked the memory of the Persian wars in order to seal the bond between the cities, the Athenians now extend the situation to interpersonal sexuality. Of course, Aphrodite is also responsible for the peace between the cities, as demonstrated in the play. She now concentrates on forming the new marital bond of the reunion of the sexes, understood as remarriage.

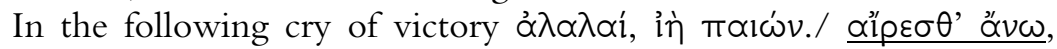

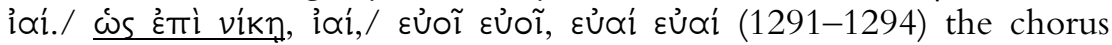
with its leaps ${ }^{48}$ and paean calls ${ }^{49}$ refers both to the intra-fictional victory and triumph over the sexual emergency and also extra-fictionally to the victory in the city's Comic agon. The refrain is both Apolline and Bacchic in the spirit of the Dionysian merry-making procession or revelry,

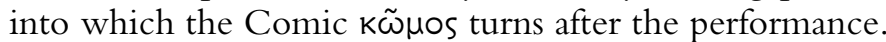

Now the united Spartan chorus is again requested - perhaps again by Lysistrata - to perform 'a new Muse on the New' (1295).$^{50}$ Whereas the male Spartan chorus has earlier sung a song on the peace of the city, it now sings a wedding song in Spartan dialect, to match the Athenian chorus of the united couples. This song alludes to Alcman's partheneia:

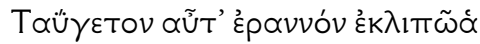

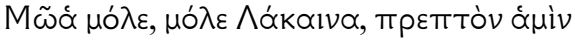

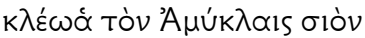

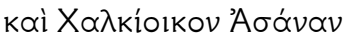

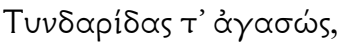

47 Calame 1977 I, 174-90 (Engl. 1997, 91-101) (on Artemis), 190-209 (Engl. 1997, 101-13) (on Apollo); on Apollo as god of male initiation see Bierl 1994.

48 The instruction to leap into the air ( alp $\left.\rho \sigma \theta^{\prime}{ }^{\prime \prime} \nu \omega\right)$ relates to the choral dance itself.

49 Actually only men sing the paean; though in tragedy it is also sung by women, cf. A. Th. 268; A. 245-47; Ch. 150-51; E. IA 1467-1469. On gender roles in connection with the paean see Calame 1977 I, 147-52 (Engl. 1997, 76-79) and Käppel 1992, 80-82, 328-29; Rutherford 2001, 58-59.

50 The new Muse is at the same time age-old; on the topic see Bierl 2004. On the motif of the new Muse see Alcman fr. 3.2. On 1295: according to the codices and Arnoldt 1873, 171 the line still belongs to the chorus (choral leader). The variant of the MS B ÉTi $v \varepsilon \propto v i \alpha v$ is interesting in the sense that it would imply the effect of the Spartan 'virgin song' on the 'young men'. 


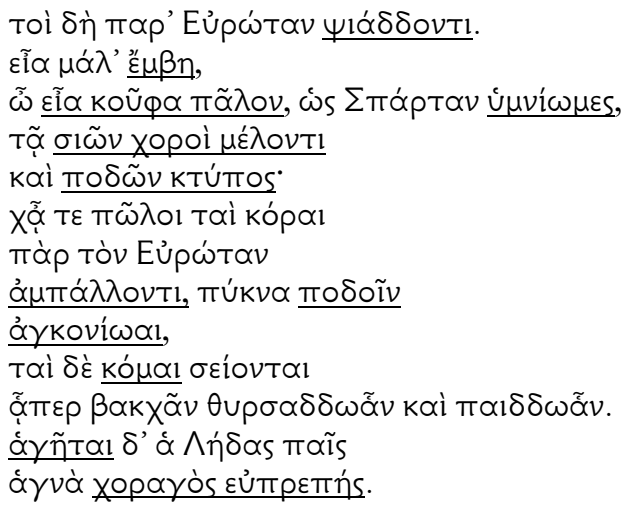

(Ar. Lys. 1296-1321)

Come back again from lovely Taygetus, Spartan Muse, come and distinguish this occasion with a hymn to the God of Amyclae and Athena of the Brazen House and Tyndareus' fine sons, who gallop beside the Eurotas. Ho there, hop! Hey there, jump sprightly! Let's sing a hymn to Sparta, home of dances for the gods and of stomping feet, where by Eurotas' banks young girls frisk like fillies, raising underfoot dust clouds; and their tresses are tossed like those of maenads waving their wands and playing. And Leda's daughter leads them, their chorus-leader pure and pretty.

Come now, band your hair with your hand, with your feet start hopping like a deer, and start clapping to spur the dance! And sing for the goddess who's won a total victory, Athena of the Brazen House!

With its dialect and local references, the Spartan chorus immediately betrays its roots in the local context. As before in the song at 12471272, it first turns to the inspirational divine power; the local Muse is supposed to come from Taygetus, in order to extol Apollo of Amyclae, Athena of the Brazen House and the excellent sons of Tyndareus. Apollo is the god associated with young people in their initiation, whereas Athena is the central goddess connecting Athens and Sparta. Athens draws its name from the eponymous goddess, who controls the Acropolis and is closely linked to Lysistrata. Athena of the Brazen House constitutes her Spartan counterpart that dominates the citadel there. After the Dioscuri, who in Sparta likewise personify the youths immediately before their wedding, there suddenly follows the choral dance in Sparta, which connects the evoked choral projection with the actual action; the sons of Tyndareus play around and gallop by the banks of the Eurotas. Then there is a choral interjection, 'Ho there hop! Hey there, 
jump sprightly!' (1302-1303) full of the self-reference with which the collective reinforces its actions in a speech act. ${ }^{51}$ The purpose of the dancing is to extol their own polis (1304). The city on the Eurotas' banks is now more closely defined: it is the place where choruses sing and dance for the gods, or choruses of the gods sing and dance themselves ( $\sigma i \tilde{\omega} v$ Xopoí, 1305) (genitive obj. or subj.). It is the place of a noisy stamping of feet as here in the frantically danced $k \tilde{\omega} \mu O S$. There girls spring like foals by the Eurotas, kicking up dust with their feet, tossing their hair, just like thyrsus-swinging and dancing maenads. This is a lightning view of the extra-fictional level of the present $k \tilde{\omega} \mu O s$ for Dionysus in mythical projection. ${ }^{52}$ The revered Helen naturally leads the chorus. ${ }^{53}$

Everything exudes the spirit of Alcman's partheneia, which manifestly take up the topic of female rites of marriage in the context of an annual festival affirming the overall order of the city and nature. ${ }^{54}$ Just as in fr. 3

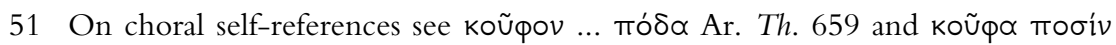

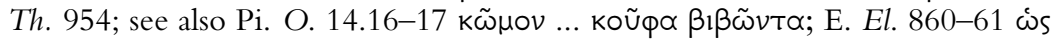

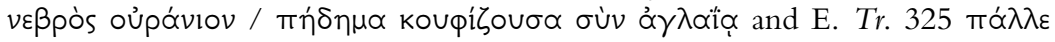

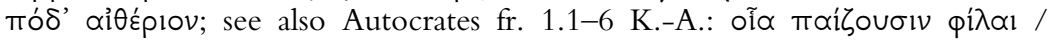

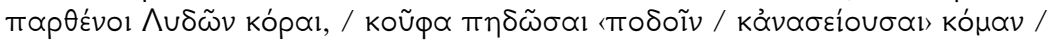
кơv $\alpha$ кроú

52 This could also be an allusion to the Dionysiades; so Calame 1977 I, 340 (Engl. 1997, 195). The college of priestesses of the eleven Dionysiades, together with the two Leucippides, performed sacrifices to Dionysus Colonatas and staged a contest for girls during the Dionysia, also called Dionysiades. On this see Calame 1977 I, 323-33 (Engl. 1997, 185-91).

53 A reference to the lovely Helen is to be found as early as in Lys. 155-56, a passage which describes Menelaus dropping his sword (with its phallic connotations) when he glimpsed the breasts of the naked Helen. Here, too, it is a matter of ousting war by erotic means, while in the context of the Trojan saga Helen functioned primarily as casus belli; the motif of beauty is of particular importance in the final song as the women, just like girls reaching the end of their initiation cycle, are now just about to marry; in this respect the song shows similarities with Theocritus's epithalamion for Helen (Id. 18); in both cases, which partly refer to Alcman fr. 1, Helen acts as the prominent choral leader.

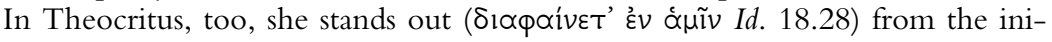
tiation group of the four times sixty girls like the dawn $(26-28,31)$ and like a speedy horse (30) racing in the Platanistas grove that is named after Helen's tree, the plane tree (21-46). Calame 1977 I, 334-40, 408 (Engl. 1997, 192-95, 236) proposes this scene as a tangible setting for Alcman fr. 1 and indirectly for Lys. 1308-1315. In my view, Aristophanes created more of a free ritual pastiche of a fantasy ritual and cited individual features of the Spartan cult.

54 On this aspect of the kosmos see Ferrari 2008. My thanks go to Gloria Pinney Ferrari for allowing me access to her manuscript before publication and for our 
PMGF, the long Louvre fragment (fr. 1) is about the choral dance itself in the ritual context of a female initiation. ${ }^{55}$ In fr. 1 PMGF (46-51, 5859) the two prima donnas are also equated with horses, and the leaping beast serves to symbolise the girls who will be tamed in marriage. At the same time, they could allude to the Leucippides, Hilaeira und Phoebe, also called $\pi \tilde{\omega} \lambda \mathrm{ol}$, who as conceptual counterparts to the Dioscuri, also called $\lambda \varepsilon v \kappa \omega \dot{\omega} \pi \omega \dot{\lambda} \omega$, are taken by them to become their wives. Gleaming horses are a symbol of the goddess of dawn Eos, who is associated with youthful beauty and for whom cult is performed in Sparta. ${ }^{56}$ The two prima donnas Agido and Hagesichora are possibly cultic personifications who re-enact the mythical heroines by way of mimessis. ${ }^{57}$ The waving hair round their whirling bodies emphasises the radiant feminine beauty with which they sexually attract the young men. ${ }^{58}$ Fair-haired Helen is the goddess of the young women on the verge of marriage $;^{59}$ she is the ideal choral leader to lead the dance; she is the symbol of all girls, chaste, and not the legendary unfaithful wife. ${ }^{60}$ The self-

extensive discussions in Washington. Although Ferrari argues in favour of a highly dramatic performance celebrating the coming of the winter season and tentatively links it with the Karneia, and towards the end of her book (Ferrari 2008, 149-50) even entertains the possibility that we may have male choreuts impersonating women who impersonate stars - if she is right, obviously this song cannot be a partheneion in the traditional sense -, I am sympathetic with her view that this is a song performed at a central polis-festival and that it extends to the cosmos and stars. Integrating Ferrari 2008 and Stehle 1997, 73-88 I tend to go beyond the mono-functional interpretation of female initiation rites by Calame and also associate the rich festival scenario, expressed by metaphors, with the dimensions of the cosmos, vegetation, New Year and polisorder.

55 In relation to initiation see also the Habilitationsschrift of Eveline Krummen she is currently preparing the manuscript for publication. I would like to thank her for letting me read her chapter on Alcman.

56 See the reference to the goddess Aotis (Alcman fr. 1.87 PMGF).

57 Nagy 1990, 346.

58 On the value of beauty see Specht 1989 and now van Wees 2003, 1-10. In the ritual context of Athens see Brulé 1987, 301-02 and Index under 'belle'.

59 On Helen in the context of initiation see Calame 1977 I, 333-57, 443, 447 (Engl. 1997, 191-206, 260, 262) and Bierl 2001, 256, 260-61 (Engl. 2009, 225, 229-30).

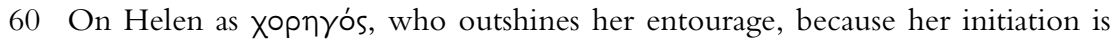
completed, see Calame 1977 I, 92, 127 n. 170, 136, 345-46, 397-98 (Engl. 1997, 42-43, 65 n. 170, 70, 199, 229-30). In the Platanistas by the banks of the river Eurotas Helen, as the personification of the maiden whose initiation is over and whose marriage is imminent, is celebrated with a running contest and dances; in Therapne, by contrast, the aspect of the married woman and goddess 
referentiality of the choral activity and the relationship between the collective and their leader in the festive context, lauding the theme of marriage as the goal of the initiation phase, play an important role in Alcman's maiden songs. In a projection of the local choral song culture, Aristophanes' united Spartan chorus becomes the partheneion that evokes Alcman and illustrates the play's reunion. As the Dioscuri and the Hippocoontidae (in the mythical part of Alcman's first five strophes that have not been transmitted complete) mythically represented the male, sexually aroused $k \tilde{\omega} \mu O S$ - compare the designation of a phallus as a white horse ( $\Sigma$. Lys. 191 and Hsch. 1 845) - so too the Leucippides and, indeed, Helen, the paragon of beauty, are the chorus dancers' mythical counterparts, who, as is well known, were snatched from their own choral groups to be married off. In a final call to itself, the chorus once more refers to their hair that should be banded by their hands, to their free movements and leaps like those of a hind, and to the noise of the stamping feet ${ }^{61}$ that 'supports the choral dance' by giving the beat. The song sung by all, then, closes with an appeal to extol the greatest goddess, who has won a total victory, Athena Chalcioecus, the holy virgin of the Bronze Temple.

This final call has again - according to the second person singular been interpreted as an appeal for a final song by a solo singer (no longer extant). Such erroneous performance allocations have sought to place lines 1273 to 1294 after 1321, because it was believed that a final song could be created in this way. ${ }^{62}$ This final appeal focuses on the crucial divinity of this comedy. Athena plays a central role in the two cities. In the series of gods mentioned by the Athenians (1279-1290), however, she was left out. The Spartan version stresses the belligerent traits of this goddess in her epicletic name, and she was defined in masculine terms in Athens too, despite her female gender. Just like Aphrodite she vanquishes all: ${ }^{63}$ the common enemies of the future, but also all the difficulties of the past. She melts into both man and woman, Sparta and Athens,

is central; her husband Menelaus is also revered there; see Calame 1977 I, 33350 (Engl. 1997, 191-202) and Larson 1995, 80-81.

61 The hind also serves as a symbol of the young girl before her wedding. See also Bierl 2001, 101-102 (Engl. 2009, 80).

62 Srebrny 1961; Henderson 1980, 217: 'At this point the text must be rearranged (van Leeuwen): lines 1273-94, which ought to end the play (1292ff. is identical with the close of other comedies), were inserted by the archetype in the wrong place. The Spartan's first song should be followed by 1295-1321; 1273-94 end the play. There is no need to assume the loss of the ending.' In his 1987 commentary Henderson no longer takes this line.

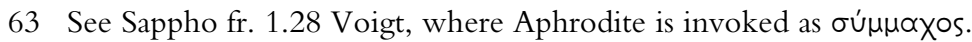


something which happens at a physical and emotional level, particularly in the joint choral dance. By means of the notion projected by the Spartan secondary chorus, the exodos synchronises the totality of Athenian and Spartan, female and male rites: the Panathenaea are complemented by the Hyacinthia and Karneia ${ }^{64}$ which all recreate marriage, and thus order, through the union of the maiden and ephebic choruses. The peace between Athens and Sparta (1289-1290) is backed up by the peace of Alcman, who extols the fact that initiation has climaxed in

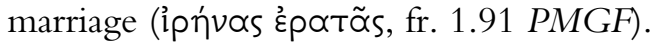

The allusions to Alcman can be summarised up in the following overview: ${ }^{65}$

Lysistrata

$\underline{\text { Alcman }}$

Place: Sparta

Cultic context: female initiation and wedding

Mythical theme: fight against men, threat of rape, war transferred into the plot as developed hitherto

placed in the mythical

part 1.1-39;

cf. $\gamma \propto \mu \tilde{\eta} \nu(1.17)$

Content: Choral dance

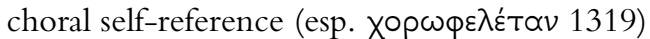

choral self-reference

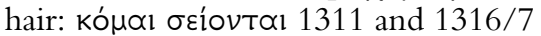

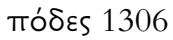

fr. $1.50-59,101 ;$ fr. 3.9

xoparós 1315

fr. $1.48,78$; fr. 3.10 and 70

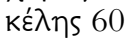

fr. 1.44; fr. 10b.11 Hagesidamus (ephebic male chorus!)

white horse as animal sacrifice 191

fr. 1.50

$\pi \tilde{\omega} \lambda$ ol 1307

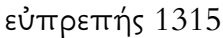

Leucippides

Horses Agido and Hegesichora as models, fr. 1.46-51, 58-59

દ̇ктрєти́s fr. 1.46 (see also Sappho fr. 96.6-9)

64 See also E. Hel. 1465-1470. The chorus imagines how Helen fits into the cultic

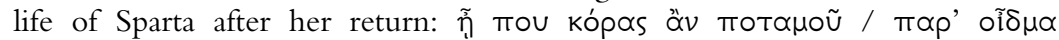

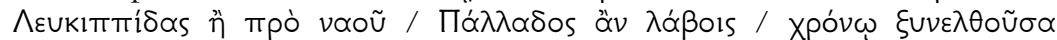

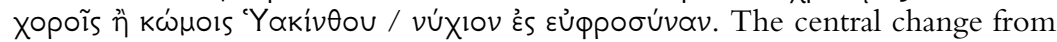
suffering to elation, so central to comedy, characterises the three-day festival of the Hyacinthia. Choral dances by both sexes at the Panathenaea (E. Heracl. 77783), choruses during the Hyacinthia (E. Hel. 1465-1470) and the performance of the Alcman's partheneion (fr. 1 PMGF) took place in the night before dawn. On Spartan festivals with the role of match-making see Pettersson 1992; on this function of the Panathenaea see Baudy 1992, 44. Here, too, the likewise relevant arrhephoroi or their mythical counterparts, i.e. the daughters of Cecrops, are envisaged in girls' choruses, where they dance in the dark caves of Pan on the northern slope of the Acropolis (E. Ion 492-500).

65 See also Cavallini 1983, 74-75 and Kugelmeier 1996, 73-75. 
noise of stamping feet:

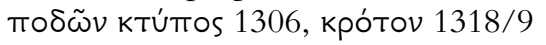

к $\propto \nu \propto \chi \propto ́ \operatorname{To\delta ~} \propto$ fr. 1.48

Number of choral dancers:

12 (half-chorus)

$10+2$ chorus-leaders (Leucippides)

or 11 Dionysiades +1

Helen (model) and $12+$ female crowd Helen (?) and $12+240$ (Theoc. Id. 18)

Helen and beauty of the Spartan women/

Lampito

beauty of chorus-leader and Helen as model

Muse

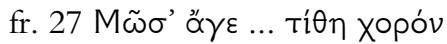

new Muse/new song 1295

fr. 3.2

Leucippides 1307

Phoebe and Hilaeira fr. 8.2

Dioscuri 1300

Apollo 1298

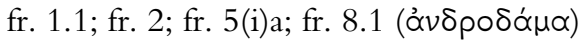

Hyacinthia

Amyclae 1298

fr. 10 a. 5

Eurotas 1301, 1308

fr. 10 a. 8

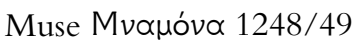

fr. $10 \mathrm{a} .7$

for 1279-1290:

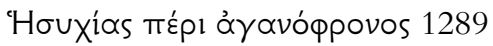

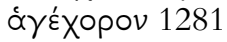

Aphrodite, Cypris 1290

Charites 1279

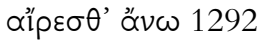

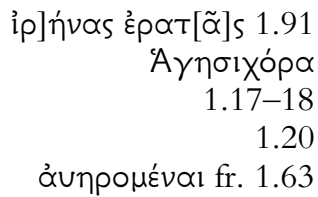

\section{Conclusion}

Wilamowitz was the first to note the reference to Alcman; yet he saw in these lines of Lysistrata a mockery of the 'village-clownish fantasy of Alcman' and a parody of the 'Alcman-like naivety' ${ }^{\prime 6}$ typical of all Spartans, which may be more true of the previous song (1247-1272). Since he assumed it was a monody, he did not think of a partheneion, rather considering the use of Alcman to be a way of making the Other, i.e. the strange character and the female manner of the long-haired Spartans, look ridiculous. ${ }^{67}$ But when hearing or reading the Spartan

66 Wilamowitz-Moellendorff 1900, 88 nn. 2 and 92.

67 Wilamowitz-Moellendorff 1900, 92: 'Dann fordert sich der Sänger selbst zum Sprunge auf, macht also einen, zu Spartas Ehren, und was er nun hervorhebt, dass Sparta an Götterchören und Fusstampfen Freude hat, wird so ausgeführt, dass das Wesentliche der Tanz der Jungfrauen ist: dem Athener sind, wie natürlich, die Partheneia, die Jungfrauentänze und Lieder, die seiner Sitte fremd sind, für Sparta das Characteristische.' ('Then the singer calls on himself to leap and does so in honour of Sparta, and what he now stresses, namely that Sparta 
dialect, one should not just see its negative, parodic aspects. Perusino has shown that the language and rhythm used here is anything but the reflection of the coarse, earthy utterances of peasant bumpkins. Rather it meets the standards of the language of high art and, above all, resembles the cultic language of Sparta. ${ }^{68}$ Willi also brought out the fact that this passage (1302-1315) is used for the purpose of 'de-Othering' the former opponents through its reference to high pan-Hellenic literature common to all, i.e. the language of elevated Doric choral poetry which gave a sense of Hellenic identity to all Greeks, in order thus to enable their mutual integration and transformation into allies. ${ }^{69}$ Calame placed the song in the context of the Spartan cult of Helen (with reference to E. Hel. 1465-1477 and Theoc. Id. 18) and recognised its close relationship with Alcman's Louvre-partheneion, whose 'Sitz im Leben' he defined as being the ritual run at the Platanistas. ${ }^{70}$ In a recent essay, Calame reaffirms the reference to Alcman, although concentrating in his analysis solely on the linguistic aspect of a shift of the agents; in his solo, the Spartan delegate would now become the inspired singer Alcman, whose accompanying group of dancers is personified by the girls (170); he himself is said to become their chorus-leader (choregos), as he also merges with Helen in the mimesis. ${ }^{71}$

I have brought out the crucial relation to the plot of Lysistrata: on the basis of the numerous choral self-references, the last song is in my view - as was already clear from the manuscripts ${ }^{72}$ - really choral; in a multi-media performance, the chorus seals the final union and plotresolution over two stages; the implicit reference to Alcman's partheneia in the last song is not accidental, but everything points to initiation, to choral groups on the threshold of marriage. The collective remarriage as a performative act finally annuls the separation of the sexes. The reference to Alcman at the same time conveys the atmosphere of peace, so important both in the maiden songs and at the end of a comedy - the atmosphere of the kosmos, i.e. of order in the political field and in the whole universe. The ritual creates cohesion within the plot, but also causes a shift of focus to the effect of the choral dance at the level of the

enjoys choruses to the gods and foot-stamping, is in such a way performed that the essential thing is the dance of the virgins: of course, for the Athenian the partheneia, the virgin dances and songs foreign to his mores, are characteristic of Sparta.' See also 91 ad 1313.

68 Perusino 1998.

69 Willi 2001, 139-41, 149.

70 Calame 1977 I, 333-50 (Engl. 1997, 191-202) and Calame 1977 II, 119-28.

71 Calame 2004, 162-72, esp. 170-71.

72 See the apparatus to lines 1279 and 1296. 
here-and-now of the performance, to which the play will immediately revert after 1321. Aristophanes once again founds his art entirely on cultic, ritual discourses. It is via the chorus and this interchoral play that the symbolic-conceptual content of a simple plot, seeming rather foreign to naturalistic theatre traditions, can be truly rendered. This interpretation thereby opens up a completely new horizon for understanding Aristophanic poetics. ${ }^{73}$

73 In the latest interpretation of the end of Lysistrata Revermann 2006, 254-60, esp. 257-59 completely overlooks the intertextual reference to Alcman. He does, however, note the Spartan colouring of the song Lys. 1296-1321, but offers a quite different, speculative explanation on a mere philological basis, namely that the passage was added later. Adopting a supposition of Taplin 1993, 58 n. 7 ('I am strongly of the opinion that Lysistrata did not originally end with the Spartan song of 11. 1296-1321; and I even have doubts whether this lyric is the work of Aristophanes rather than a lyric poet originally composing for a Spartan audience'), he presents the hypothesis that these lines were inserted for a later performance in the Spartan colony of Taras in Lower Italy, in order to emphasise the link to the parent city of Sparta by complementing the cultic connections. Revermann thereby also attempts to interpret the content of line 1295 , which is about a 'new song', as a kind of meta-theatrical reference to this new ending. 